\title{
Historadiographic Observations on the Outer Dentin in Certain Osseous Fishes
}

\author{
by \\ Sohiti ISOKAWA, ${ }^{*}$ Ichiro SATOMURA, ${ }^{*}$ Kunimitsu YAMAGUCHI,
Tamotsu YOSHIE* and Masao MORIMOTO*
}

In 1900, C.S. Tomes[1] in his observations on the fish teeth stated that in fish teeth the dentin is exposed from the enamel cap to the supporting bone and although it seems to be an easy task whether the dentin is covered with a thin layer of enamel or not, it is actually a very difficult one (Fig. 1). This dentin is called "Kragen" by SCHMIDT and KeIL[2] and "outer dentin" by IsoKawa[3], one of the present authors.

The surface of this dentin is given by TOMES to be brittle and become dissolved by the presence of an acid. On the other hand, CARTER[4] stated that in the teeth of hake the surface of outer dentin lacks any indication of enamel.

The authors concerned themselves with historadiographic observations of certain fish teeth of this outer dentin in certain fish teeth so as to contribute toward an elucidation of the long-standing problem.

\section{Materials and Method}

Three species of fishes: Pagrossomus major, Semicossphus reticulatus and Haplognathus fasciatus were selected for study purposes, as the jaw teeth in these fishes are relatively large and easy to manage.

Upon removal, the jaw teeth were embedded in polyester resin and longitudinally sectioned to the thickness of $100-150 \mu$ by the use of a thin sectioning machine.

These sections were further ground down to about $40-70 \mu$ by the use of Arkansas stone.

Historadiographs were taken of their thin ground sections by Softex CMR-type ultra X-ray unit, subsequent observations being conducted microscopically by comparing them with the sections.

Some of the ground sections were subjected to a weak acid treatment so that their dissolved state could be also studied.

\section{Observations}

Relationship of the supporting bone for the jaw teeth differed from fish to fish (Table 1, Fig. 2). In the ground section the enamel cap is revealed tubular structure

\footnotetext{
*磯川宗七, 里邨一郎, 山口国光, 吉江保, 森本昌男: Department of Anatomy, Nihon Univ. School of Dentistry, Tokyo, Japan.
} 


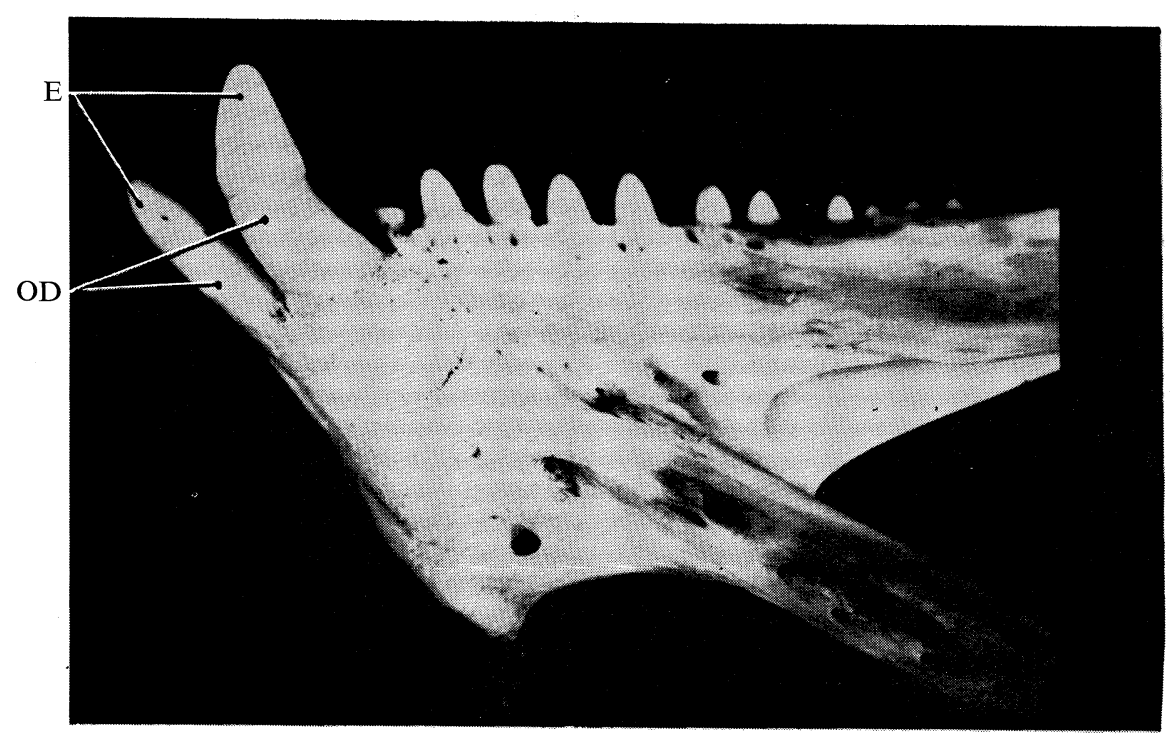

Fig. 1 A dental bone of Semicossphus reticulatus $\times$ ca 25 E: tubular enamel (enamel cap) OD: outer dentin

Table 1 Manner of the supporting bone to jaw teeth

\begin{tabular}{|c|c|}
\hline Fish & Relationship of the supporting bone \\
\hline Pagorssmus major & $\begin{array}{l}\text { Connected via translucent zone *existing between the } \\
\text { supporting bone and teeth }\end{array}$ \\
\hline Semicossphus reticulatus & Teeth joined to the supporting bone by ankylosis \\
\hline Haplognathus fasciatus & Teeth joined to the supporting bone by ankylosis \\
\hline
\end{tabular}

and the outer layer of dentin is shown as a similar structure to the tubular enamel (Fig. 3). Outer dentin joined to dentin by what is called "Grenzfasserchicht" by Morgenstern[6]. But outer dentin layer from the adjacent spot of enamel cap to the supporting bone gave the nearly uniform thickness. It was not possible to determine from the ground section whether or not outer dentin was covered with enamel or enamel-like substance.

From the historadiographic observation, both enamel cap and surface layer of outer dentin were seen to show an intensive X-ray absorption, where the hypercalcification was suspected. The rest of outer dentin revealed the same structure as dentin (Fig. 4). As is known from Fig. 4, the range of X-ray opaque outer dentin is wide at the enamel cap and then gradually narrows toward the supporting bone, tapering to a complete disappearance at the bony trabeculae or just before the contact area. 
The manner of X-ray absorption by this hypercalcified surface layer is very similar to that of tubular enamel. But when a ground section of a tooth was placed under the microscope and subjected to a weak acid treatment, enamel became almost completely dissolved whereas outer dentin did not quite disappear (Fig. 3). Even if the surface layer gave an appearance of a partial dissolution, the structure remained in the radioopaque region inspite of decalcification when examined microscopically.

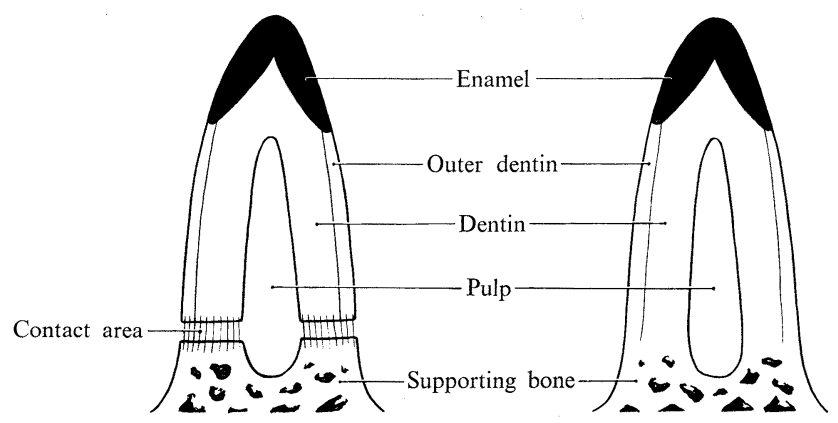

b

Fig. 2 Diagrammatic illustration of two types of the attachment found between a tooth and its supporting structure

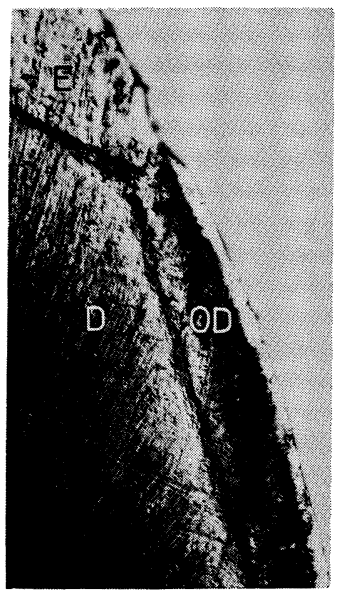

a

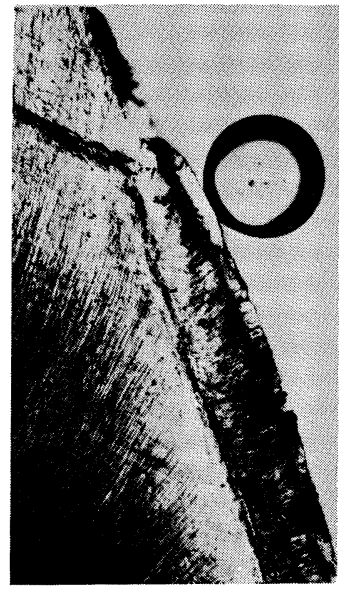

b

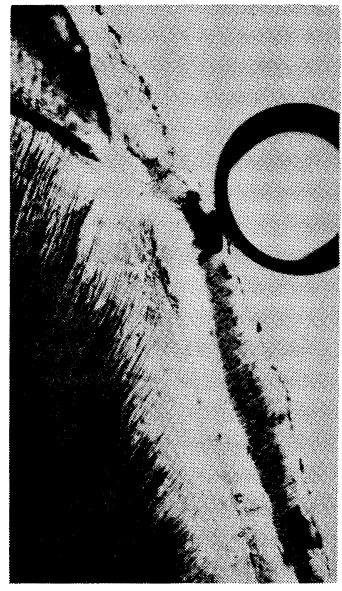

c

Fig. 3 Decalcifying processes of a ground section $\times$ ca 40

a: non-treatment

b: initial decalcifying stage

c: further decalcifying stage

E: tubular enamel

D: dentin

OD: outer dentin 


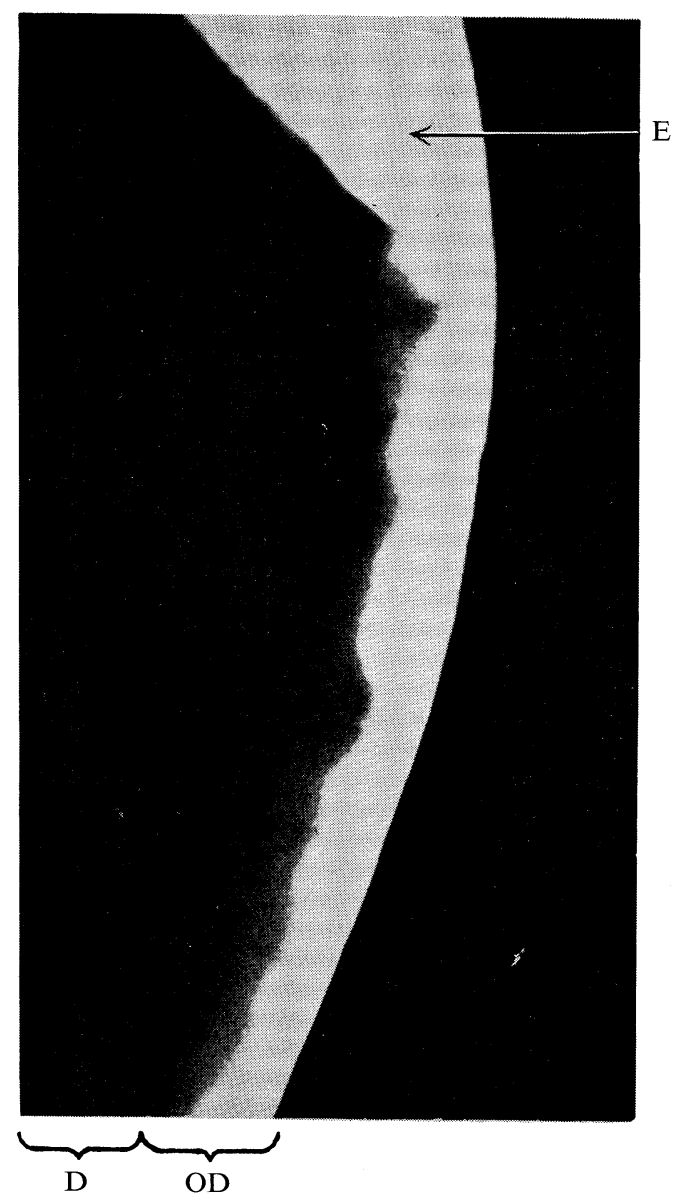

Fig. 4 Histogradiograph of the tooth of Semicossphus reticulatus $\times$ ca 50 E: tubular enamel

D: dentin

OD: outer dentin

\section{Discussion}

With small fish, it is very difficult to determine whether the matrix of teeth is covered with enamel or not.

In 1955, IsOKAWA[7] predicted that a very thin layer of hypercalcification existed on the surface of scombroid fish teeth, basing his reasoning on the light reflection seen on the tooth surface. His use of light reflection as evidence for his argument indicates how difficult it is to study a thin hypercalcified layer on the fish teeth.

In the present study, the teeth taken from relatively larger fish were used but, even so, the findings of the authors did not exceed the description given by TOMES years ago.

Although the application of historadiography was able to determine the existence 
of hypercalcified region in the outer dentin, we failed to determine definitely whether it belonged to dentin or to enamel. The result of decalcifying examination by the use of a weak acid led us to incline to the view that this structure rather belonged to dentin. If this impression of ours should prove correct, then it will follow that this outer layer has become hypercalcified to a higher degree than other regions through the deposition of minerals there owing to its exposure to much irritation from outside.

CARTER[4] and SATOMURA[8] maintain that ameloblastic-covering cells surrounding the outer dentin in the developing stage of teeth are cuboidal in shape. But the authors consider these cells to be highly columnar and this finding also lends support to our explanation of hypercalcified region on the outer dentin.

\section{Conclusions}

Historadiographic technique was applied in determining whether or not the outer dentin of jaw teeth taken from three fish species: Pagrossmus major, Semicossphus reticulatus and Hoplogpathus fasciatus, was covered with enamel.

The salient conclusion was as follows.

1. The existence of hypercalcified layer on the outer dentin having the same radiopacity as enamel was historadiographically confirmed.

2. Although a definite evidence that hypercalcified surface layer of the outer dentin was enamel could not be found in terms of decalcificying examination and histologic findings of teeth in the developing stage, this portion of the outer dentin was thought to be highly calcified through the deposition of minerals owing to much external irritation there.

\section{References}

[1] Tomes, C. S.: Upon the development of the enamel in certain osseous fish; Phil. Trans. Roy Soc., Ser. B, 193, 35-46, (1900).

[2] Schmid, W. J. and KeIL, A.: Die gesunden und die erkrankten Zahngewebe des Menschen und der Wirbeltiere in Polarisationsmikroskop; Carl Hanser, München, S. 167-182, (1958).

[3] IsoKawA, S.: Morphological studies on the teeth of fishes. I On the teeth of porgies; Japan. J. Ichthyol, 3, 68-78, (1954), (in Japanese).

[4] Carter, J. T.: On the cytomorphosis of the enamel organ in the hake; Ouart. J. Micr. Sci., 63, 387-400, (1918).

[5] Isokawa, S., Onuma, H. and Yoshida, H.: Pharyngeal teeth of pogies; J. Nihon Univ. Sch. Dent., 2, 86-90, (1959).

[6] Morgenstern, M.: Die Grenzfaserschicht; im Beitrage zur Histologie des Zahnbeins; Arch. Anat. u. Physiol., 331-338 (1909).

[7] IsokawA, S.: Morphological studies on the teeth of fishes. III. On the teeth of scombroid fishes; Japan. J. Ichthyol., 4, 201-206, (1955), (in Japanese):

[8] Satomura, I.: A study on outer dentin of some teleostal fish teeth; Nihon Univ. dent. J., 43, 473-442, (1969), (in Japanese) 